\title{
Transmembrane Signaling and T-Cell Immunodeficiency
}

\author{
ERWIN W. GELFAND \\ Division of Basic Sciences, Department of Pediatrics, National Jewish Center for Immunology and Respiratory \\ Medicine, Denver, Colorado 80206
}

\begin{abstract}
Activation of T cells after ligation of the antigen-specific $T$-cell receptor initiates a cascade of metabolic and biochemical alterations that culminate in cell proliferation. The major changes include a series of phosphorylation reactions on numerous protein substrates, phosphatidylinositol hydrolysis, intracellular $\mathrm{Ca}^{2+}$ accumulation, gene activation, lymphokine receptor expression, and lymphokine secretion. Despite a great deal of work unraveling the structure of the $T$-cell receptor complex and the many biochemical events triggered by ligation of the $T$-cell receptor, the exact link between the various responses is not entirely defined. Nevertheless, abnormalities in any of these initial events may be presumed to have an impact on signal transduction, thereby resulting in a $\mathrm{T}$-cell immunodeficiency. Such defects may be restricted to certain T-cell subsets or functions or represent more global defects. (Pediatr Res 33 (Suppl): S16-S19, 1993)
\end{abstract}

\section{Abbreviations}

APC, antigen-presenting cell

NF-AT, nuclear factor of activated $T$ cells

PLC, phospholipase C

PTK, protein tyrosine kinase

TCR, T-cell receptor

$\left(\mathrm{Ca}^{2+}\right)_{\text {in }}$, free cytosolic $\mathrm{Ca}^{2+}$

Ins: $\mathrm{P}_{3}$, inositol trisphosphate

For the purposes of this review, several aspects need to be considered. First, the activation of $T$ cells is somewhat different from the activation of other cells. T-cell activation is dependent on cell-cell contact between an APC and the T cell. The ligand for the TCR is the peptide-MHC complex presented by the APC. Second, ligation of the TCR complex leads to expression of lymphokine receptors and lymphokine secretion. This autocrine pathway results in $T$-cell proliferation. Third, in consideration of potential T-cell defects as a result of a signaling abnormality, we must also delineate whether only the $T$ cells express a particular protein required for activation or whether all cells express this protein but only $\mathrm{T}$ cells are dependent on it for normal function.

For the most part, the defects considered are likely to be genetic in nature, leading to the early onset of symptoms of Tcell immunodeficiency. Acquired abnormalities of signal transduction could result from viral infection (e.g. AIDS) or drugs (e.g. the immunosuppressants cyclosporin A or FK506). Figure 1 illustrates one scheme for T-cell activation focusing on a number of presumed critical events. Abnormalities of signal

Correspondence: Erwin W. Gelfand, M.D., Division of Basic Sciences, Department of Pediatrics, National Jewish Center for Immunology and Respiratory Medicine, Denver, CO 80206. transduction can take several forms or be expressed on different cell types including the APC, the lymphokine-secreting cell, and the lymphokine-responsive cell. The defects may reside in expression of critical surface molecules or receptors or pivotal enzymes, genes, or their enhancing proteins. The synchrony of all these events is required for the initiation and continuance of cell cycle progression and the general increases in protein, lipid, and RNA synthesis.

\section{APC}

To effectively present antigen, APC generate immunogenic peptides from the more complex parent protein. These peptides may then be bound to an MHC class II molecule, and it is this complex on the surface of the APC that serves as the stimulatory ligand for the TCR. The generation of immunogenic peptides and intracellular trafficking of peptide-MHC is slowly being unraveled. A series of mutant APC has been generated with defects in antigen presentation in spite of normal class II expression $(1,2)$.

Several patients have been described with defective expression of HLA class I and class II proteins (3-5). In general, these patients have near-normal mitogen-induced proliferative responses but absent antigen-specific responses.

A number of accessory molecules may play a role in efficient coupling of APC and antigen-specific T cells. These include CD28 on T cells and its ligand on APC, and a variety of adhesion molecules, including ICAM-1 and LFA-1. Defects in adhesion molecule expression have more commonly been associated with defective neutrophil function and not primarily with $\mathrm{T}$-cell immunodeficiency (6).

\section{LYMPHOKINE SYNTHESIS AND SECRETION}

Central to the $\mathrm{T}$-cell proliferative response is the synthesis and secretion of the IL. The majority of the work has focused on the events that regulate induction of IL-2 synthesis. It is likely that the production of IL-4 is similarly regulated. As with the majority of activation genes, transcriptional regulation accounts for most of the levels of IL gene expression (7). Our data indicate that the increases in IL-2 gene transcription and synthesis/secretion are critically dependent on increases in concentrations of $\left(\mathrm{Ca}^{2+}\right)_{\mathrm{i}}(8)$. Increases in cytosolic $\mathrm{Ca}^{2+}$ may be achieved by release of $\mathrm{Ca}^{2+}$ from sequestered stores, primarily the endoplasmic reticulum; transmembrane uptake of $\mathrm{Ca}^{2+}$; and a decrease in $\mathrm{Ca}^{2+}$ extrusion by the $\mathrm{Ca}^{2+}$ pump. Transmembrane uptake of $\mathrm{Ca}^{2+}$ resulting in sustained increases in $\left(\mathrm{Ca}^{2+}\right)_{i}$ appears to be the essential component: store release alone is insufficient. Calcium uptake across the T-cell plasma membrane is likely through ligand-gated but not voltage-gated $\mathrm{Ca}^{2+}$ channels (9).

The stimulus for opening the plasma membrane $\mathrm{Ca}^{2+}$ channel is unclear. There are three consistent, early responses that follow ligation of the TCR complex. The first is phosphatidylinositol hydrolysis resulting in the liberation of $\operatorname{InsP}_{3}$ and diacylglycerol 


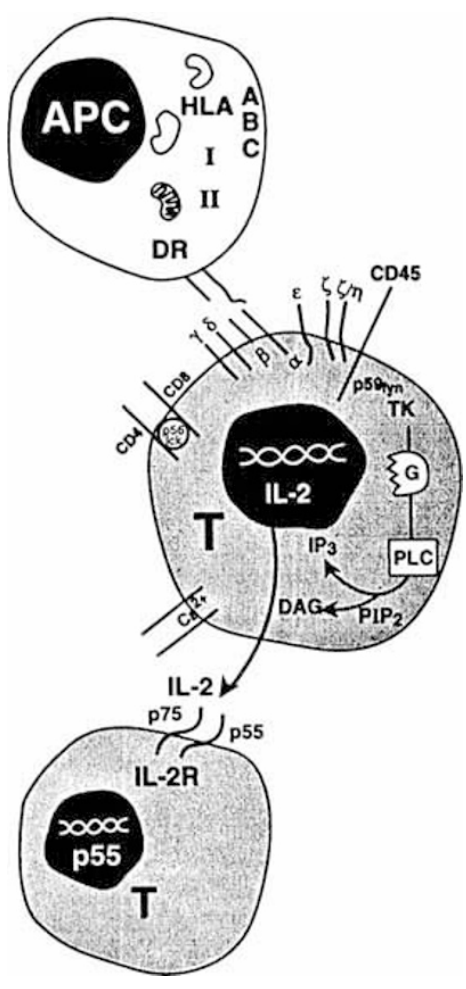

CRITICAL EVENTS

1. Processing

2. Presentation

3. TCR/CD3 Complex

4. $C D 45$

5. p59 fyn

5a. Tyrosine Kinase -p56 lck

6. G protein

\section{Phospholipase $\mathrm{C}$}

8. $\mathrm{Ca}^{2+}$ channels

9. IL-2 gene

9a. IL-2 Promoters -NF-AT

10. IL-2 Receptor

Fig. 1. Critical events in T-cell signaling

(10). The former results in the liberation of $\mathrm{Ca}^{2+}$ from internal stores and the latter in the activation of protein kinase $C$. The second early response is the increased phosphorylation of several proteins on tyrosine residues by PTK. This includes the phosphorylation of the CD- $\zeta$ chain, a postulated critical early event $(11,12)$. The third response is the major increase in $\left(\mathrm{Ca}^{2+}\right)_{i}$ due to transmembrane uptake of $\mathrm{Ca}^{2+}$ through ligand-gated $\mathrm{Ca}^{2+}$ channels (13). These three responses have been linked: inhibition of tyrosine phosphorylation abolishes changes in inositol phosphate metabolism and $\mathrm{Ca}^{2+}$ mobilization. However, the exact sequence and regulation of the critical events remains to be defined as discussed below.

Gating or opening of these channels is regulated at several different levels including the state of membrane potential at the time of TCR engagement (14), the level of $\left(\mathrm{Ca}^{2+}\right)_{\mathrm{i}}(13)$, and possibly by $\mathrm{InsP}_{3}$ or a phosphorylated derivative, $\operatorname{InsP}_{4}(15)$. The role of PTK in T-cell activation has been implicated in studies using inhibitors such as genistein or herbimycin that block $\mathrm{Ca}^{2+}$ responses and $\mathrm{Ins}_{3}$ generation (16). T cells contain at least three members of the src family of nonreceptor PTK genes: lck, fyn, and yes $(17,18)$. The p56 $6^{\text {lck }}$ kinase and an isoform of $\mathrm{p} 59^{\text {fyn }(\mathrm{T})}$ are found almost exclusively in T lymphocytes $(18,19)$. Crosslinking of CD4 or CD8 activates lck $(20,21)$ and is associated with phosphorylation of the CD3- $\zeta$ chain (21). p59 fyn interacts with the CD3 subunits (22), likely serving as a primary signal transduction element of the CD3/TCR complex. Both lck and fyn have been implicated in tyrosine phosphorylation of the $\zeta$ chain. The relationship between tyrosine phosphorylation of the $\zeta$ chain and TCR function is not clear (22). In the absence of the $\zeta$ chain, there is incomplete assembly of CD3/TCR complex (23). Tyrosine phosphorylation of the $\zeta$ chain may be required for IL-2 production in response to antigen (24).

At least part of the control of $\zeta$ chain phosphorylation may reside in the phosphatase activity of CD45. This surface glycoprotein with tyrosine phosphatase activity appears to be essential for CD3/TCR-associated increases in $\left(\mathrm{Ca}^{2+}\right)_{i}(25)$.

After TCR stimulation, PLC is phosphorylated and activated $(11,26-28)$. Several studies have linked the phosphorylation of PLC with PTK causing phosphorylation of other proteins, e.g. p59 $9^{f y n}$. Attempts to show that PLC activation is regulated by a $G$ protein coupled to the CD3/TCR have been inconclusive (29).

Assimilating all these data into a scheme for $\mathrm{T}$-cell activation indicates that induction of IL-2 synthesis requires the activation of CD45 phosphatase, the activation of at least one PTK, i.e. p $59^{f y n}$, the phosphorylation of the CD3- $\zeta$ chain on tyrosine residues, and the opening of the plasma membrane, ligand-gated $\mathrm{Ca}^{2+}$ channel. The failure to 1 ) form an intact CD3/TCR complex, 2) express these phosphatase or kinase activities, or 3) trigger $\mathrm{Ca}^{2+}$ influx is associated with a failure to trigger IL-2 gene transcription. The role of $\mathrm{p} 56^{\text {lck }}$ in this cascade is unclear at present, although absence of this kinase is associated with a marked arrest of T-cell development at an early stage of ontogeny and T-cell lymphopenia (30). These conclusions are based on in vitro experiments with mutant cell lines or recent investigations using transgenic mice.

A defect localized to an impaired association of the CD3- $\zeta$ chain with other chains of the CD3/TCR complex has been described in a Spanish family (31). This resulted in impaired surface expression of the CD3/TCR complex. Surprisingly, both mild and severe clinical presentations were noted, perhaps correlating with levels of TCR surface expression. Most T-cell immune deficiencies are characterized by normal $\mathrm{Ca}^{2+}$ influx but are associated with a failure to initiate IL-2 gene transcription. There have been some notable exceptions, but the pathogenesis of the abnormalities is unclear (32, unpublished observations).

These early activation events somehow link surface receptormediated phenomena to the nuclear induction of several critical activation genes. Transcriptional regulation accounts for most of the regulation of T-cell activation genes. A variety of nuclear or enhancer proteins interacting with specific regulatory sequences within these gene segments play a major role as targets for signals after antigen-receptor ligation. The important enhancer protein for IL-2 (and perhaps IL-4) is located in the $5^{\prime}$ flanking sequences of the IL-2 gene and has been identified as NF-AT (7). Activation of NF-AT appears dependent on $\mathrm{Ca}^{2+}$ mobilization, presumably $\mathrm{Ca}^{2+}$ influx. The influx of $\mathrm{Ca}^{2+}$ is perhaps most critical for the nuclear shuttling of a constitutively expressed cytoplasmic component of NF-AT (33). Together with an inducible nuclear component of NF-AT, the complex positively regulates IL-2 gene activation (33). The immunosuppressants cyclosporin A and FK506 interfere with this shuttling, preventing IL-2 gene activation. The mechanism of inhibition is not clear but may be related to the effect of these drugs on the important calciumcalmodulin-dependent phosphatase, calcineurin (34). Although not exclusively expressed in $\mathrm{T}$ cells, the relative restriction of NF-AT to $\mathrm{T}$ cells makes it a possible candidate for T-cell immunodeficiency. Indeed, a patient with severe combined immunodeficiency and phenotypically normal $T$ cells but deficient mRNA coding for IL-2, IL-3, IL-4, and IL-5 has been linked to an abnormal NF-AT nuclear transcription complex $(35,35 \mathrm{a})$.

\section{IL-DEPENDENT CELL PROLIFERATION}

Whereas the signaling requirements for IL secretion are relatively stringent, the expression of functional high-affinity receptors, including IL-2R, are less so. It is unclear what are the essential activation signals required for IL-receptor expression. In the case of the IL-2R, $\mathrm{Ca}^{2+}$ mobilization does not appear essential (8). Specific defects in IL-receptor expression have not yet been described except for the possibility of IL-1R (36).

Because IL-2 functions as a progression signal, ligation of the receptor activates a number of pathways and substrates. Activation of the IL-2R does not result in $\mathrm{Ca}^{2+}$ mobilization or phosphatidylinositol hydrolysis $(37,38)$. IL-2 increases tyrosine phosphorylation of a number of intracellular proteins and the phosphorylation of several kinases including MAP-2 kinase and S6 kinase $(38-41)$. The role of p56 ${ }^{l c k}$ in IL-2-dependent signaling may be important as this kinase is activated after IL-2 binding to its receptor $(42,43)$. Because some IL-2-responsive cell lines 
lack $\mathrm{p} 56^{\text {lck }}$, it may not be essential for IL-2-dependent signaling (38). None of these pathways appears unique to $T$ cells, so any possible defect presumably would affect many different cell types. Because the immunosuppressant rapamycin is a potent inhibitor of IL-2-mediated cell proliferation (44), definition of its point of action may reveal some unique signaling pathway.

\section{SUMMARY}

The multiplicity of signaling pathways activated by ligation of TCR complexes is slowly being unraveled. They provide many targets for disruption with the potential for a T-cell immunodeficiency state to emerge. On the other hand, few of these pathways are restricted solely to $T$ cells. Moreover, there is a certain redundancy in these pathways, which provides little opportunity for one component to be absolutely essential. Nevertheless, careful evaluation of these processes will likely lead to the definition of new disorders and, hopefully, innovative therapies.

\section{REFERENCES}

1. Mellins E, Smith L, Arp B, Cotner T, Celis E, Pious D 1990 Defective processing and presentation of exogenous antigens in mutants with normal HLA class II genes. Nature 343:71-74

2. Mellins E, Arp B, Singh D, Carreno B, Smith L, Johnson AH, Pious D 1990 Point mutations define positions in HLA-DR 3 molecules that affect antigen presentation. Proc Natl Acad Sci USA 87:4785-4789

3. Schuurman RKB, Gelfand EW, Touraine JL, Van Rood JJ 1980 Lymphocyte membrane abnormalities associated with primary immunodeficiency disease. In: Primary Immunodeficiencies, INSERM Symposium No. 16, Elsevier Science Publishers, Amsterdam, pp 87-99

4. Lisowska-Grospierre B, Charron DI, de Préval C, Durandy A, Turmel P, Griscelli C, Mach B 1984 Defect of expression of MHC genes responsible for an abnormal HLA class I phenotype and the class II negative phenotype of lymphocytes from patients with combined immunodeficiency. In: Histocompatibility Testing. Springer-Verlag, Berlin, pp 650-655

5. Niethammer D, Dopfer R, Dammer G, Peter H, de Préval C, Mach B, Hadam MR 1986 Congenital agammaglobulinemia associated with malabsorption: no expression of MHC-class II antigens due to a regulatory gene defect? In: Aiuti F, Rosen FS, Cooper MD (eds) Recent Advances in Primary Immunodeficiencies, Serono Symposia 28. Raven Press, New York, pp 185-193

6. Fischer A, Lisowska-Grospierre B, Anderson DC, Springer TA 1988 Leukocyte adhesion deficiency: molecular basis and functional consequences. Immunodefic Rev 1:39-54

7. Ullman KS, Northrop JP, Verweij CL, Crabtree GR 1990 Transmission of signals from the $T$ lymphocyte antigen receptor to the genes responsible for cell proliferation and immune function: the missing link. Annu Rev Immunol 8:421-452

8. Mills GB, Cheung RK, Grinstein S, Gelfand EW 1985 Increase in cytosolic free calcium concentration is an intracellular messenger for the production of interleukin 2 but not for expression of the interleukin 2 receptor. $J$ Immunol 134:1640-1643

9. Gelfand EW, Mills GB, Cheung RK, Lee JWW, Grinstein S 1987 Transmembrane ion fluxes during activation of human T lymphocytes: role of $\mathrm{Ca}^{2+}$, $\mathrm{Na}^{+} / \mathrm{H}^{+}$exchange and phospholipid turnover. Immunol Rev 95:59-87

10. Weiss A, Imboden JB 1987 Cell surface molecules and early events involved in human $T$ lymphocyte activation. Adv Immunol 41:1-38

11. Baniyash M, Garcia-Morales P, Luong E, Samelson LE, Klausner RD 1988 The T-cell antigen receptor zeta chain is tyrosine phosphorylated upon activation. J Biol Chem 263:18225-18230

12. Hsi ED, Siegel JN, Minami Y, Luong ET, Klausner RD, Samelson LE 1989 $T$ cell activation induces rapid tyrosine phosphorylation of a limited number of cellular substrates. J Biol Chem 264:10836-10842

13. Gelfand EW, Cheung RK 1990 Dissociation of unidirectional influx of external $\mathrm{Ca}^{2+}$ and release from internal stores in activated human $\mathrm{T}$ lymphocytes. Eur J Immunol 20:1237-1241

14. Gelfand EW, Cheung RK, Mills GB, Grinstein S 1987 Role of membrane potential in the response of human $\mathrm{T}$ lymphocytes to phytohemagglutinin. J Immunol 138:527-531

15. Gardner P 1989 Calcium and T lymphocyte activation. Cell 59:15-20

16. Mustelin T, Coggeshall M, Isakov N, Altman A 1990 T cell antigen receptormediated activation of phospholipase $\mathrm{C}$ requires tyrosine phosphorylation. Science 247:1584-1587

17. Perlmutter RM, Marth JD, Ziegler SF, Garvin AM, Pawar S, Cooke MP, Abraham KM 1988 Specialized protein tyrosine kinase proto-oncogenes in hematopoietic cells. Biochim Biophys Acta 984:245-262

18. Cooke MP, Perlmutter RM 1989 Expression of a novel form of the fyn protooncogene in hematopoietic cells. New Biol 1:66-74

19. Voronova AF, Adler HT, Sefton BM 1987 Two lck transcripts containing different $5^{\prime}$ untranslated regions are present in T cells. Mol Cell Biol 7:44074413

20. Rudd CE, Trevillyan JN, Dasgupta JD, Wong LL, Schlossman SF 1988 The
CD4 receptor is complexed in detergent lysates to a tyrosine kinase (pp58) from human T lymphocytes. Proc Natl Acad Sci USA 85:5190-5194

21. Veillette A, Bookman MA, Horak EM, Bolen JB 1988 The CD4 and CD8 T cell surface antigens are associated with the internal membrane tyrosineprotein kinase $\mathrm{p} 56^{\text {lck }}$. Nature 338:257-259

22. Samelson LE, Phillips AF, Loving ET, Klausner RD 1990 Association of the fyn protein tyrosine kinase with the T cell antigen receptor. Proc Natl Acad Sci USA 87:4358-4362

23. Sussman JJ, Bonifacino JS, Lippincott-Schwartz J, Weissman AM, Saito T, Klausner RD, Ashwell JD 1988 Failure to synthesize the $T$ cell CD3-zeta chain: structure and function of a partial $\mathrm{T}$ cell receptor complex. Cell 52:8595

24. Frank SJ, Niklinska BB, Orloff DG, Mevcep M, Ashwell JD, Klausner RD 1990 Structural mutations of the T cell receptor zeta chain and its role in T cell activation. Science 249:174-177

25. Koretzky GA, Picus J, Thomas ML, Weiss A 1990 Tyrosine phosphatase CD45 is essential for coupling $\mathrm{T}$-cell antigen receptor to the phosphatidyl inositol pathway. Nature 346:66-68

26. Granja CL, Lin L, Yunis EJ, Relias V, Dasgupta JD 1991 PLC-1: a possible mediator of T cell receptor function. J Biol Chem 266:16277-16280

27. Weiss A, Koretsky G, Schatzman RC, Kadlecek T 1991 Functional activation of the T-cell antigen receptor induces tyrosine phosphorylation of phospholipase C-1. Proc Natl Acad Sci USA 88:5484-5488

28. Park DJ, Rho HW, Rhee SG 1991 CD3 stimulation causes phosphorylation of phospholipase $\mathrm{C}-1$ on serine and tyrosine residues in a human $\mathrm{T}$ cell line. Proc Natl Acad Sci USA 88:5453-5456

29. Rao A 1991 Signaling mechanisms in T cells. Clin Rev Immunol 10:485-519

30. Perlmutter RM 1993 Molecular dissection of lymphocyte signal transduction pathways. Pediatr Res 33(suppl):S9-S15

31. Alarcon B, Regueiro JR, Arnaiz-Villena A, Terhorst C 1988 Familial defect in the surface expression of the T-cell receptor CD3 complex. $\mathrm{N}$ Engl $\mathrm{J}$ Med 319:1203-1208

32. Chatila T, Wong R, Young M, Miller R, Terhorst C, Geha RS 1989 An immunodeficiency characterized by defective signal transduction in $\mathrm{T}$ lymphocytes. N Engl J Med 320:696-702

33. Flanagan WM, Corthésy B, Bram RJ, Crabtree GR 1991 Nuclear association of a T-cell transcription factor blocked by FK-506 and cyclosporin A. Nature 352:803-807

34. Liu J, Farmer Jr JD, Lane WS, Friedman J, Weissman I, Schreiber SL 1991 Calcineurin is a common target of cyclophilin-cyclosporin A and FKBPFK506 complexes. Cell 66:807-815

35. Chatila T, Castigli E, Pahwa R, Chirmule N, Oyaizu N, Good RA, Geha RS 1990 Primary combined immunodeficiency resulting from defective transcription of multiple T-cell lymphokine genes. Proc Natl Acad Sci USA 87:10033-10037

35a. Castigli E, Geha RS, Chatila T 1993 Severe combined immunodeficiency with selective T-cell cytokine genes. Pediatr Res 33(suppl):S20-S23

36. Chu ET, Rosenwasser LJ, Dinarello CA, Rosen FS, Geha RS 1984 Immunodeficiency with defective T-cell response to interleukin 1. Proc Natl Acad Sci USA 81:4945-4949

37. Mills GB, Cheung RK, Grinstein S, Gelfand EW 1985 Interleukin 2-induced lymphocyte proliferation is independent of increases in cytosolic free calcium concentrations. J Immunol 134:2431-2435

38. Sawami H, Terada N, Franklin RA, Okawa H, Uchiyama T, Lucas JJ, Gelfand EW 1992 Signal transduction by interleukin 2 in human $T$ cells: activation of tyrosine and ribosomal S6 kinases and cell-cycle regulatory genes. J Cell Physiol 151:367-377

39. Ferris DK, Brown JW, Ortaldo JR, Farrar WL 1989 IL-2 regulation of tyrosine kinase activity is mediated through the $p$ 70-75 $\beta$-subunit of the IL-2 receptor. J Immunol 143:870-876

40. Mills GB, May C, McGill M, Fung M, Baker M, Sutherland R, Greene WC 1990 Interleukin 2-induced tyrosine phosphorylation: interleukin 2 receptor $\beta$ is tyrosine phosphorylated. $\mathrm{J}$ Biol Chem 265:3561-3567

41. Saltzman EM, White K, Casnellie JE 1990 Stimulation of the antigen and interleukin 2 receptors on $\mathrm{T}$ lymphocytes activates distinct tyrosine protein kinases. J Biol Chem 265:10138-10142

42. Hatakeyama M, Kono T, Kobayashi N, Kawahara A, Levin SD, Perlmutter RM, Taniguchi T 1991 Interaction of the IL-2 receptor with the $s r c$-family p56 $6^{\text {lck: }}$ identification of novel intermolecular associations. Science 252:15231528

43. Horak ID, Gress RE, Lucas PJ, Horak FM, Waldmann TA, Bolen JB 1991 Tlymphocyte interleukin 2-dependent tyrosine protein kinase signal transduction involves the activation of $\mathrm{p} 56^{\text {lck }}$. Proc Natl Acad Sci USA 88:1996-2000

44. Dumont FJ, Melino MR, Staruch JM, Koprak SL, Fisher PA, Sigal NH 1990 The immunosuppressive macrolides FK 506 and rapamycin act as reciprocal antagonists in murine T cells. J Immunol 144:1418-1424

\section{FLOOR DISCUSSION}

Dr. Pahwa: You mentioned that IL-2 receptor expression is independent of calcium mobilization. Is that true for mRNA for both IL-2 receptor and surface IL-2 receptor expression? As you know, there is some evidence that posttranscriptional regulation of IL-2-receptor expression might be calcium dependent.

Dr. Gelfand: The big change is in p55 message and protein 
expression since p75 is constitutively on, so you do not need a change in the levels of free cytosolic calcium. Remember, this does not mean that it is not calcium dependent in terms of what is already within the cytosol. I am just talking about the need for calcium mobilization to detect a change from baseline levels.

Dr. Sorenson: What kind of stimuli activate the IL-4-driven proliferation? Have you identified some kind of antigen that would interact with the $\alpha / \beta$ chains and trigger this kind of proliferation?

Dr. Gelfand: In terms of IL-4 itself driving the IL-4 receptor and causing the cells to proliferate, there is no evidence now for tyrosine phosphorylation, calcium influx, or IP (inositol phosphate) metabolism. Whether other phosphoglycans are involved is unclear at the present time. In terms of driving it specifically, even in a calcium-independent fashion, the best recognized form is using a combination of anti-CD28 antibody with a phorbol ester. That will certainly drive the IL-4 system, in fact even more than IL-2 in our hands, and that again is in the absence of calcium.

Dr. Levinson: Dr. Gelfand, let me throw out a naive possibility to explain the dissociation that you saw in the patient whose double-positive thymocytes proliferated, and you saw only CD4 cells out in the periphery. Is it possible that you are getting a calcium boost in a double-positive population of cells that otherwise would be differentiating toward CD8? You get that signal, and those cells are induced to undergo apoptosis; whereas the cells that are going to differentiate along the CD4 pathway do not get that initial calcium signal so that they don't undergo programmed cell death. The latter cells may get out into the periphery, but because they are lacking some pathway that is involved in that calcium signal they cannot proliferate once they get out there.
Dr. Gelfand: In fact, that is one of the hypotheses that we have developed, that it is a leak-through, that it bypasses the apoptotic mechanism. That is why I asked Dr. Perlmutter about the role of $\mathrm{p} 59$, because one could also speculate that the cells may be overexpressing p59 at a double-positive stage and escaping the apoptotic mechanism only in one lineage, not in CD8 but in the CD4 population. On seeing Dr. Perlmutter's data, one wonders about the overexpression of p59 in these patients. The knockout experiments that he talked about, which Tak Mak has done, and also the types of experiments that Dr. Perlmutter has done have led to a deficiency of both CD4 and CD8 in the periphery, at least in the mouse. That is where there is a bit of a discrepancy.

Dr. Strober: Is it possible that in some of these situations the mechanism of cell activation and calcium influx is, in a sense, decoupled from the mechanisms that are necessary for activating lymphokine genes and lymphokine receptor genes? Could it be that we would find normal calcium influx and normal phospholipid turnover and so on, but we are not looking in the right place in terms of what is really necessary for generation of the nuclear binding factors required for the gene activation events?

Dr. Gelfand: Yes, it is possible. I think this is an important question because the overwhelming majority of the patients who have had abnormal proliferative responses or abnormal IL synthesis, even the SCIDs (patients with severe combined immunodeficiency disease) who have very few $\mathrm{T}$ cells, flux calcium perfectly normally. So the inability to flux calcium in $\mathrm{T}$ cells of these immunodeficient patients is actually rare. That leads to the question: Is calcium absolutely necessary or is that a bit of a red herring? Perhaps the cells that are present, despite their ability to flux calcium, do not have the subsequent mechanisms that are required for the transcriptional regulation of these important lymphokines. 